\title{
Evaluation of the influence of mechanical activation on physical and chemical properties of municipal solid waste incineration sludge
}

\section{Citation for published version (APA):}

Caprai, V., Florea, M. V. A., \& Brouwers, H. J. H. (2018). Evaluation of the influence of mechanical activation on physical and chemical properties of municipal solid waste incineration sludge. Journal of Environmental Management, 216, 133-144. https://doi.org/10.1016/j.jenvman.2017.05.024

\section{Document license:}

TAVERNE

DOI:

10.1016/j.jenvman.2017.05.024

Document status and date:

Published: 15/06/2018

\section{Document Version:}

Publisher's PDF, also known as Version of Record (includes final page, issue and volume numbers)

\section{Please check the document version of this publication:}

- A submitted manuscript is the version of the article upon submission and before peer-review. There can be important differences between the submitted version and the official published version of record. People interested in the research are advised to contact the author for the final version of the publication, or visit the DOI to the publisher's website.

- The final author version and the galley proof are versions of the publication after peer review.

- The final published version features the final layout of the paper including the volume, issue and page numbers.

Link to publication

\footnotetext{
General rights

- You may freely distribute the URL identifying the publication in the public portal. follow below link for the End User Agreement:

www.tue.nl/taverne

\section{Take down policy}

If you believe that this document breaches copyright please contact us at:

openaccess@tue.nl

providing details and we will investigate your claim.
}

Copyright and moral rights for the publications made accessible in the public portal are retained by the authors and/or other copyright owners and it is a condition of accessing publications that users recognise and abide by the legal requirements associated with these rights.

- Users may download and print one copy of any publication from the public portal for the purpose of private study or research.

- You may not further distribute the material or use it for any profit-making activity or commercial gain

If the publication is distributed under the terms of Article 25fa of the Dutch Copyright Act, indicated by the "Taverne" license above, please 
Research article

\title{
Evaluation of the influence of mechanical activation on physical and chemical properties of municipal solid waste incineration sludge
}

\author{
V. Caprai*, M.V.A. Florea, H.J.H. Brouwers \\ Department of Built Environment, Eindhoven University of Technology, Eindhoven, 5600 MB, The Netherlands
}

\section{A R T I C L E I N F O}

\section{Article history:}

Received 30 January 2017

Received in revised form

13 April 2017

Accepted 8 May 2017

Available online 13 May 2017

\section{Keywords:}

MSWI sludge

Reactivity

Mechanical activation

Leaching

\begin{abstract}
A B S T R A C T
Despite numerous studies concerning the application of by-products in the construction field, municipal solid waste incineration (MSWI) residues are not widely used as secondary building materials. In some European countries, washing treatment to the full bottom ash (BA) fraction $(0-32 \mathrm{~mm})$ is applied, isolating more contaminated particles, smaller than $0.063 \mathrm{~mm}$. Therefore, a MWSI sludge is produced, having a high moisture content, and thus a limited presence of soluble species. In order to enhance its performance as building material, here, dry mechanical activation is applied on MSWI sludge. Thereafter, a reactivity comparison between reference BA and untreated and treated MSWI sludge is provided, evaluating their behaviour in the presence of cement and their pozzolanic activity. Moreover, the mechanical performances, as $25 \%$ substitution of Portland cement (PC) are assessed, based on the EN 450. Mechanical activation enhances MSWI sludge physically due to the improved particle morphology and packing. Chemically, the hydration degree of PC is enhanced by the MSWI sludge by $\approx 25 \%$. The milling treatment proved to be beneficial to the residues performances in the presence of PC, providing $32 \%$ higher strength than untreated sample. Environmentally, the compliance with the unshaped material legislation is successfully verified, according to the Soil Quality Decree.
\end{abstract}

๑) 2017 Elsevier Ltd. All rights reserved.

\section{Introduction}

In recent times, the management of municipal solid waste (MSW) has become important to guarantee an economically and environmentally sustainable way of living. After collection, MSW is initially processed in waste-to-energy plants, by incineration. The created municipal solid waste incineration (MSWI) residues consist of various products such as bottom ash (BA) (80\% wt.), grate siftings, heat recovery ash, fly ash and air pollution control residues. Despite the risk of releasing harmful substances into the soil (Sabbas et al., 2003; Florea, 2016), in the EU, BA is usually applied for road construction or landfilled (Allegrini et al., 2015; Forteza and Far, 2004; Hjelmar, 1996; Lam et al., 2010; Lin et al., 2012). Due to the increasing environmental concern, since 2011, the Netherlands defined stricter limitations for leaching of contaminants from landfilled materials (Soil Quality Decree, 2015), aiming to reduce the number of landfilling sites and to address the design of secondary raw materials from incineration by-products (Zhen et al., 2013). Nowadays, various applications of bottom ash (BA) in

\footnotetext{
* Corresponding author.

E-mail address: v.caprai@tue.nl (V. Caprai).
}

the construction field have been studied (Bertolini et al., 2004; Boesten et al., 2012; Polettini et al., 2009; Revathi et al., 2014). Among them, the application of BA as inert replacement of Ordinary Portland Cement (PC) has found successful, up to $30 \%$ of the binder mass (Kula et al., 2002; Tang et al., 2014a; Targan et al., 2003). Before being reused, BA undergoes additional treatments, such as removal of ferrous and nonferrous compounds, in order to achieve a more homogeneous and less contaminated material (Keulen et al., 2012). Among these procedures, a washing separation treatment is applied to the full fraction of BA (below $32 \mathrm{~mm}$ ), isolating most of the incineration residues smaller than $0.063 \mathrm{~mm}$, generally more contaminated (Biganzoli, 2012; Alam et al., 2016). Therefore, a MWSI sludge is produced characterized by a high moisture content (MC), and consequently limited ions available for dissolution. Due to the restrained application of this washing separation treatment, the use of MSWI sludge as secondary building material is generally not taken into account outside the Netherlands. Consequently, to the authors' knowledge, the investigation of MSWI sludge is not extensively performed, due to the low availability of the by-product in Europe. Furthermore, the storage conditions of MSWI sludge lead to particles agglomeration, increasing the particle size of the supplied material. As mentioned, 
due to the source of this by-product, the monitoring of contamination levels and leaching is also a concern. In addition to this, the initial MC of MSWI sludge favors the dissolution of soluble phases, reducing the final reactivity of the by-product.

The suitability of a by-product as cement replacement is linked to its chemical and physical contribution to the PC hydration. In general, the reactivity of ashes is affected by many aspects, from the source of the waste to its collection and disposal. In the case of low reactivity ashes, many studies propose activation treatments to increase the final dissolution of particles (Cheriaf et al., 1999; Onori et al., 2011; Polettini et al., 2009; Qiao et al., 2009, 2008; Tang et al., 2014b). There are three main methodologies applied for this purpose: thermal, chemical and mechanical activation (MA). Thermal activation is not suitable from an environmental point of view, due to the high incineration temperature (between $800^{\circ} \mathrm{C}$ and $1500^{\circ} \mathrm{C}$ ) (Hernández-Montoya et al., 2012; Zhen et al., 2013). Chemical activation of MSWI residues is not always possible, due to the potential high organic content of the by-products (Fernández-Jiménez and Palomo, 2003; Sathonsaowaphak et al., 2009). Therefore, economically and environmentally, the most sustainable method for increasing the reactivity of ashes is MA. Generally, MA improves the bulk and surface area of the solid through physicochemical changes (Kumar and Kumar, 2011), which might lead to the acquisition of additional pozzolanic activity. However, the mineralogical changes are not always remarkable in case of MA of ashes (Temuujin et al., 2009). Its application is beneficial also due to the formation of smaller less reactive particles (external core of coarser particles), which act as a filler among cement grains (Hela and Orsáková, 2013). Increasing the fineness, the prolonged grinding rises the amount of active centres with higher energy state respect to the rest of the structure. The more of those sites, the faster the rate of reactivity in the presence of PC (Onori and Polettini, 2011; Sajedi and Razak, 2011; Temuujin et al., 2009). Until now, the application of MA on MSWI sludge has not been deeply investigated. However, the improvement achieved can lead to performances comparable to BA fines, favouring the application of MSWI sludge in the construction field. Since the behaviour of BA fines as cement replacement has been more extensively studied, a comparison with this residue provides a useful reference for the evaluation of MSWI sludge performances.

This study provides an evaluation of the influence of MA on MSWI sludge, compared with reference fines of two streams of BA. The enhancement of MSWI sludge properties aims to achieve comparable results with BA in mechanical and environmental performances, in order to provide an alternative application for this municipal residue. Firstly, the by-products provided by Heros Sluiskil (NL) are characterized physically and chemically. Additionally, the MSWI treated sludge is compared to the untreated material and reference $\mathrm{BA}$, regarding the impact of the MA on physical properties. Thereafter, this paper will address the reactivity of the two reference streams of BA and MSWI sludge (before and after MA), based on the pozzolanic activity index and by isothermal calorimetry analysis. Finally, the application of the byproducts as secondary building materials is evaluated by the strength activity index and by the one stage batch leaching test, for the compliance to the Dutch SQD legislation for the unshaped (granular) material (“Soil Quality Decree," 2015).

\section{Experimental}

\subsection{Materials}

Three different streams of MSWI residues are considered in this study: two types of bottom ash fines (BA1 and BA2) and MSWI sludge (Ss), all coming from Heros Sluiskil (NL). All the MSWI residues are characterized by a particle size below $0.250 \mathrm{~mm}$. After dividing the BA full fraction in a coarse and a fine particle size streams (Bac and BAf, respectively), a wet separation treatment is initially applied to produce sludge, by removal of fine residues from the BAc. The MSWI sludge is further processed by using a centrifuge to limit the water content of the final product. In parallel, the fine size stream (BAf) is fractioned and particles below 0.250 were isolated (BA1). Part of the BA1 is further clean, by air separation removal, limiting the presence of the ultrafine ash particles, forming BA2. Due to the agglomeration of particles caused by the storage conditions, the application of Ss as untreated material is not possible. Hence, in this study, an implementation by MA was attempted for this residue, and compared with the two BA streams, for evaluation. The pozzolanic activity of BA1, BA2 and MSWI sludge was evaluated in the presence of calcium hydroxide $(\mathrm{CH})(\mathrm{CH} \geq 96 \%$ pure, Fluka Analytical), CEM I $42.5 \mathrm{~N}$ (PC) and inert standard sand (98\% $\mathrm{SiO}_{2}$, Norm sand, ISO 679, EN 196-1). The analysis of reactivity was performed without any additional laboratory treatment, since the washing processing might affect the final dissolution rate of the by-products in water.

\subsection{Methods}

\subsubsection{Characterization of the raw materials}

Firstly, all materials were dried at $50{ }^{\circ} \mathrm{C}$ for $72 \mathrm{~h}$, to constant mass. The PSD was measured by laser diffraction (Mastersizer 2000, Malvern). The specific gravity of the dry powders was tested by Helium pycnometer (AccuPyc II 1340), while the bulk density by a conventional pycnometer. The chemical composition of the byproducts was determined by X-ray Fluorescence spectrometer (PANalytical Epsilon 3 range, standardless OMNIAN method), on pressed powder. The specific surface area and total pore volume were measured using nitrogen adsorption measurements (Micromeritics, Tristar II 3020 V1.03). The water demand of the powders was measured by the Puntke test (Hunger and Brouwers, 2009). Information about the morphology of the particles was provided by Scanning Electron Microscopy (SEM, Quanta 650 FEG, FE). The analysis was performed in high vacuum, at chamber pressure of 0.6 mbar, spot size 3.0, voltage $20.0 \mathrm{KV}$ and in low vacuum by coupling large field detector, GSED detection (LFD) and BSE- detector, at chamber pressure 0.6 mbar, spot size 4.0, voltage $10 \mathrm{KV}$. The quantification of $\mathrm{CaCO}_{3}$ was computed from the $\mathrm{CO}_{2}$ mass loss between 640 and $740{ }^{\circ} \mathrm{C}$ (Gabrovšek et al., 2006), with thermogravimetric analysis (TGA), using Jupiter STA 449 F1, Netzsch, heating rate $5{ }^{\circ} \mathrm{C} / \mathrm{min}$, purged with $\mathrm{N}_{2}$ and synthetic air. The evaluation of the metallic Al content was performed by treatment in alkaline environment (3 M NaOH solution) for $24 \mathrm{~h}$ (Porciúncula et al., 2012). The loss of ignition was evaluated by heating the samples to $1100{ }^{\circ} \mathrm{C}$ for $4 \mathrm{~h}$ and measuring the mass loss at constant $\mathrm{RH}$. The evaluation of the $\mathrm{Ca}^{2+}$ ions dissolution in the presence of water was measured by ion chromatography (IC) (Thermoscientific Dionex ICS-1100), after $1 \mathrm{~h}$, at $20^{\circ} \mathrm{C}$.

\subsubsection{Mechanical activation treatment of MSWI sludge}

The MA of Ss was carried out using a Fritsch Pulverisette 5 planetary ball mill, at a constant speed of $200 \mathrm{rpm}$. Bottom ash particles are characterized by a rigid inner core, mainly composed of stony or glassy material, and a surrounding loose coating layer in the order of few hundred microns, composed by ultrafine ash particles. Due to its structure, composed by light materials as organic matters, fine melt glass and remnants of metallic matter, this layer is defined as "fragile zone" and it contributes to the increase of the final porosity in BA particles (Saffarzadeh et al., 2011). Due to the presence of these dust-like residues on the Ss particles surface and its fine PSD, zirconia grinding balls size $10 \mathrm{~mm}$ were 
chosen. This setup aimed to limit the further increase of specific surface area (SSA), by avoiding high speed collisions caused by the use of high rotational speed and balls size. The excessively high SSA would further increase the water demand of the blended mixtures, preventing its application in cementitious systems. A material to media ratio $1: 1$ by weight was maintained during the MA (according to the instruction of the planetary mill ball) and three treatment periods were selected $(30,60,90 \mathrm{~min})$. The samples were consequently named as Ss 30 , Ss60 and Ss90, respectively. The procedure paused at intervals of $15 \mathrm{~min}$, for $5 \mathrm{~min}$, to avoid overheating the sample.

\subsubsection{Evaluation of the pozzolanic activity of MSWI residues}

The pozzolanic activity of the considered BA streams and the treated and untreated MSWI sludge was evaluated chemically, according to the ISO recommendation R 863-1968 (Cheriaf et al., 1999), which defines the pozzolanic activity by the reduction in $\mathrm{Ca}^{2+}$ ions, when a pozzolan reacts in a saturated lime environment. Consequently, pastes containing $50 \% \mathrm{wt}$. by-product and $50 \% \mathrm{wt}$. $\mathrm{CH}$ were mixed, with a liquid to solid ratio $(\mathrm{L} / \mathrm{S})$ of 0.8 (due to the high surface area of the ashes) and named $\mathrm{SsCH}, \mathrm{BA} 1 \mathrm{CH}, \mathrm{BA} 2 \mathrm{CH}$. The treated Ss samples were named Ss30CH, Ss60CH and Ss90CH, depending on the milling time. Specimens cured at constant $\mathrm{RH}$ (97\%) were tested by TG analysis at 7, 14, 28 days. Before each test, the pastes were placed in alcohol (2-Propanol) for $24 \mathrm{~h}$ to stop hydration and dried at $60{ }^{\circ} \mathrm{C}$ for $24 \mathrm{~h}$. The reference (named $\mathrm{q} 1 \mathrm{CH}$ ) contained $50 \%$ wt. $\mathrm{CH}$ and $50 \%$ wt. quartz (q1), acting as inert material. Here, the mass loss due to water evaporation allowed the quantification of the total $\mathrm{CH}$ available for pozzolanic reaction in the samples. The difference between those two mass losses (sample and reference) led to the reacted $\mathrm{CH}$ content in time: the higher the reacted $\mathrm{CH}$, the greater the pozzolanic activity of the ash. The temperature range selected for $\mathrm{CH}$ decomposition was $390^{\circ}-460{ }^{\circ} \mathrm{C}$ (Gabrovšek et al., 2006). The use of this methodology was initially applied for fly ash and metakaolin, but it is considered suitable also for by-products (Cheriaf et al., 1999).

\subsubsection{Kinetic study of bottom ash reactivity in the presence of cement}

The determination of the influence of the by-products on PC hydration was investigated by Isothermal Calorimetry (TAM AIR calorimeter), at 5 days of reaction. There are two main effects involved in the replacement of PC by supplementary cementitious materials: the first is the heterogeneous nucleation effect, a physical process able to influence the chemical activity of the PC, by catalysing the nucleation process on the surface of particles, extraneous to the cementitious system (Cyr et al., 2005; Lothenbach et al., 2010). The second one is the effective contribution coming from the chemical dissolution of reactive phases in the presence of water. Initially, the availability of soluble phases in water was tested, by measuring the cumulative heat on $100 \%$ byproduct pastes with an $\mathrm{L} / \mathrm{S} 0.8$. Thereafter, the quantification of the heterogeneous nucleation effect $\left(Q_{n u c l}\right)$ was estimated by cumulative heat analysis on samples prepared by $75 \%$ PC and $25 \%$ quartz, named q1PC, q2PC and q3PC, depending on the fineness of the quartz. q1 resembled the PSD of BA1 and BA2, q2 the one of Ss, while q3 mimicked the PSD of the treated samples. To define the contribution due to chemical dissolution $\left(Q_{\text {diss }}\right)$, reference sample based on plain PC was tested and compared with samples prepared with $75 \%$ wt. PC and 25\% wt. incineration residues (named SsPC, BA1PC and BA2PC). Treated MSWI sludge was also tested in the same conditions, and termed Ss30PC, Ss60PC and Ss90PC, according to the grinding times. Contrary to the TGA, all the pastes were characterized by an L/S 0.5 , as the reduced replacement level of the sludge in the presence of cement ( $25 \%$ wt.) did not affect the rheological behaviour as much as in the TG analysis, where samples are characterized by higher replacement ( $50 \% \mathrm{wt}$.). The measurement of the heterogeneous nucleation effect allows the quantification of the contribution of the chemical dissolution of the residues, using the formulas:

$Q_{\text {nucl }}=Q_{q n P C}-Q_{P C}$

$Q_{\text {diss }}=Q_{B A n P C}-Q_{q n P C}$

where, $Q_{\text {nucl }}$ is the cumulative heat contribution due to the heterogeneous nucleation effect $[\mathrm{J} / \mathrm{g}], \mathrm{Q}_{\mathrm{qnPC}}$ is the cumulative heat developed by the mixture PC + quartz [J/g], $Q_{P C}$ is the cumulative heat of plain PC $[\mathrm{J} / \mathrm{g}], Q_{\text {diss }}$ is the contribution caused by the dissolution of reactive phases in $\mathrm{BA}[\mathrm{J} / \mathrm{g}]$ and $\mathrm{Q}_{\mathrm{BAnPC}}$ is the cumulative heat of the mixture MSWI residues + PC [J/g]. Each contribution calculated by Formula (1) and (2) was expressed in the graph as rate of the plain PC cumulative heat. In order to evaluate the contributions of the by-products on the PC hydration, the normalization of the cumulative heat trends were based on the mass of PC. Moreover, the cumulative heat measurements were collected after $20 \mathrm{~min}$ from the beginning of the reaction, to avoid the influence of stirring time and ensure the stabilization of the calorimetry conditions.

\subsubsection{Evaluation of the strength activity index}

The slump flow of the pastes evaluated the rheological behaviour achieved before and after the grinding procedure, at different milling times. The flowability of the fresh mortars was determined using the flow table test according to EN 1015-3 (EN 1015-3, 2007). The final $\mathrm{L} / \mathrm{S}$ ratio of the mortars was fixed at 0.5 . In the mortars, the sand to binder ratio was 3, while the replacement level of byproducts was set at $25 \%$, by mass of the binder. The bending strength results were based on the average of three specimens, while for the compressive strength an average of six samples is provided. The mechanical performances of the same mixtures used for the slump flow were tested according to EN 196-1 (EN 196-1, 2005) and cured at constant RH (97\%) and room temperature.

The curing procedure was not performed in water, to avoid the leaching of contaminants during the curing period. The compressive strength was measured for determining the strength activity index (SAI), according to EN 450. Although originally drafted for combustion coal fly ash, the standard EN 450 has also been used to assess the suitability of BA replacement in concrete in other studies (Cheriaf et al., 1999). The SAI calculation was based on the ratio of compressive strength at a specific curing time of specimens based on $75 \%$ wt. PC and $25 \%$ wt. ash by mass and the reference $100 \%$ PC. The replacement rate was fixed by the standard. Exceeding the value 0.75 defined the suitability of the BA as concrete replacement, as specified in EN 450. The calculation applied, for a time interval $t_{n}$ read:

$S A I_{B A(t)}=F_{B A P C(t)} / F_{P C(t)}$

where, $S A I_{B A}$ is the strength activity index, $F_{B A P C}$ is the compressive strength of the (residues $+\mathrm{PC}$ ) mix [MPa] and $F_{P C}$ is the compressive strength of plain mortars [MPa]. During the evaluation, three time intervals were used: $\mathrm{t}_{1}=7$ days, $\mathrm{t}_{2}=14$ days and $\mathrm{t}_{3}=28$ days.

\subsubsection{Environmental impact evaluation}

The environmental impact of all the different MSWI residues streams and 28 days mortars was addressed by the application of a leaching test procedure according to EN 12457-2 (one stage batch 
Table 1

Chemical composition of the incineration residues and binder included in this study, evaluated by XRF.

\begin{tabular}{|c|c|c|c|c|}
\hline \multirow[t]{2}{*}{ Compounds } & BA1 & BA2 & Ss & CEM I $42.5 \mathrm{~N}$ \\
\hline & $\%$ wt. & $\%$ wt. & \% wt. & \% wt. \\
\hline $\mathrm{Na}_{2} \mathrm{O}$ & 0.93 & 0.99 & 0.55 & - \\
\hline $\mathrm{MgO}$ & 1.67 & 1.75 & 2.35 & 1.80 \\
\hline $\mathrm{Al}_{2} \mathrm{O}_{3}$ & 7.19 & 7.87 & 9.07 & 3.93 \\
\hline $\mathrm{SiO}_{2}$ & 10.16 & 12.29 & 11.71 & 19.31 \\
\hline $\mathrm{P}_{2} \mathrm{O}_{5}$ & 1.11 & 1.06 & 0.90 & 0.8 \\
\hline $\mathrm{SO}_{3}$ & 5.99 & 5.28 & 5.07 & 3.69 \\
\hline $\mathrm{K}_{2} \mathrm{O}$ & 1.08 & 1.08 & 0.71 & 0.64 \\
\hline $\mathrm{CaO}$ & 29.63 & 27.90 & 27.26 & 64.02 \\
\hline $\mathrm{Fe}_{2} \mathrm{O}_{3}$ & 6.53 & 9.48 & 6.38 & 3.25 \\
\hline $\mathrm{CuO}$ & 0.52 & 0.67 & 0.44 & - \\
\hline $\mathrm{Cl}$ & 1.78 & 1.52 & 0.86 & 0.02 \\
\hline Other oxides & 3.41 & 3.62 & 3.01 & 1.65 \\
\hline $\mathrm{LOI}^{\mathrm{a}}$ & 30.00 & 26.50 & 31.70 & 1.25 \\
\hline
\end{tabular}

\begin{tabular}{lllll}
\multicolumn{4}{l}{ Quantification of known phases and remaining oxides } \\
\hline $\mathrm{CaCO}_{3}{ }^{\mathrm{a}}$ \\
Remaining CaO & 13.41 & 11.82 & 16.40 & - \\
Metallic Al & 21.11 & 21.27 & 20.45 & - \\
\hline
\end{tabular}

a Due to the high calcium content, all carbonated phases in BA are ascribable to calcium carbonate.

b "Remaining oxides" quantifies the $\mathrm{Ca}^{2+}$ containing phases in oxide form, which are not present as $\mathrm{CaCO}_{3}$.

leaching test) (Florea et al., 2015; Holm and Hansen, 2003) under continuous shaking (constant speed $250 \mathrm{rpm}, 20^{\circ} \mathrm{C}, 24 \mathrm{~h}$ ) (ES SM30, Edmund Buhler $\mathrm{GmbH}$ ). The suspensions were filtered with $0.017-0.030 \mathrm{~mm}$ membrane filters. The analysis of heavy metals in the leachates, was performed by inductively coupled plasmaatomic emission spectrometry (ICP-OES) according to NEN 6966 (NEN-EN, 2005), acidifying the samples with $0.2 \% \mathrm{HNO}_{3}$ beforehand. For the quantification of chloride and sulphates concentrations, ion chromatography (IC) (Thermoscientific Dionex ICS-1100) was used. The limit for the leaching of contaminants from unshaped (granular) materials were set by the Dutch Soil Quality Decree (SQD) (Soil Quality Decree, 2015). From preliminary tests, it has been determined that the results from the one stage batch leaching test (EN 12457-2) provided higher concentrations of contaminants compared to the column test, due to the more severe testing conditions (Florea et al., 2015). Therefore, the compliance to the SQD requirements in these conditions indicated the adequacy of the leachates also for the column test, applied in the SQD. As performed in other studies (Abdel-Kader et al., 2013), the retention rate, indicating the rate of retained ions in the system after leaching test in the presence of PC, was calculated using the formula:
$I=\left(r * L_{B A}\right)-\left(L_{B A r}\right) /\left(r * L_{B A}\right) * 100$

where, I is the retention rate [\%], $\mathrm{r}$ is the replacement level (25\% in this case), $\mathrm{L}_{\mathrm{BA}}$ is the incineration residue leaching for the chosen contaminant $[\mathrm{mg} / \mathrm{Kg}], \mathrm{L}_{\mathrm{Bar}}$ is the incineration residue leaching in the presence of $\mathrm{PC}[\mathrm{mg} / \mathrm{Kg}]$.

\section{Results and discussion}

\subsection{Characterization of the material}

Table 1 presents the chemical composition of the reference byproducts (BA1 and BA2), PC and Ss, evaluated by XRF. All the ashes have a similar chemical composition, with an estimated equivalent content of calcium oxide between 27 and 29\%, silica between 10 and 12\% and alumina between 7 and 9\%. This similar chemical composition allows an easier comparison among the performances of the residues. Part of the $\mathrm{Ca}^{2+}$ is not available for reaction because it is mostly bonded in $\mathrm{CaCO}_{3}$, formed during weathering. Excluding the calcium present in this form, the amount of the corresponding remaining calcium species (in form of oxides) is also provided in Table 1, under "remaining oxides". The particle morphology of untreated by-products is presented in Fig. 1a)-c). Visually, BA1 and Ss show a similar morphology, with non-spherical particles and a disorganized structure, due to the low incineration temperatures (850-900 ${ }^{\circ} \mathrm{C}$ ), applied by the incineration plant in comparison with other combustion systems (Lam et al., 2010). Contrary to BA2, which displays a smoother particle surface, BA1 and Ss exhibit ultrafine ash residues on the surface of the particles. The differences in the particles morphology are owed to the removal of the fragile zone, by air separation, which BA2 undergoes in the plant. Table 2 defines the physical properties of MSWI residues, in agreement with the SEM pictures. Compared to PC, all MSWI residues present a high total pore volume, maximized in the case of Ss. These data are correlated with the high water demand measured, indicating a physical capillary absorption of part of the water. The high total surface area, and thus water demand of BA1 an Ss is explained by the presence of ultrafine ashes characterizing the fragile zone layer on the particles surface, as it seems to supply effective porosity to the bottom ash particles (Inkaew et al., 2014; Saffarzadeh et al., 2011). On the other hand, the lower surface area and pore volume detected for BA2 reflects the uniform surface displayed in Fig. 1a). In general, the undefined morphology supports the low bulk density of the by-product, compared to PC (Table 2).

Fig. 2 provides the PSD of the reference by-products and materials used in the study. For MSWI sludge the agglomeration of

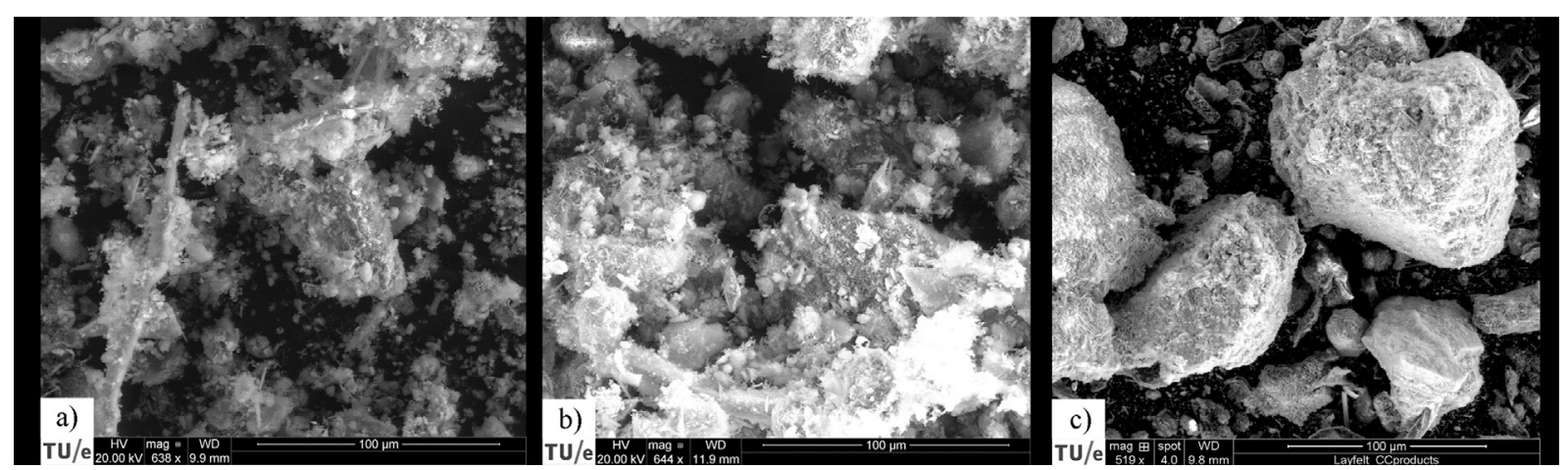

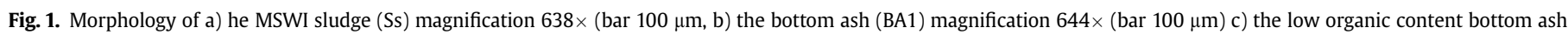
(BA2) magnification $519 \times$ (bar $100 \mu \mathrm{m}$ ). 
Table 2

Summary of the physical parameters of these MSWI by-products.

\begin{tabular}{|c|c|c|c|c|c|c|c|}
\hline \multirow[t]{2}{*}{ Mixture } & \multirow{2}{*}{$\frac{\text { Bulk density }}{\mathrm{g} / \mathrm{cm}^{3}}$} & \multirow{2}{*}{$\frac{\text { Specific gravity }}{\mathrm{g} / \mathrm{cm}^{3}}$} & \multirow{2}{*}{$\frac{\text { BET surface area }}{\mathrm{m}^{2} / \mathrm{g}}$} & \multirow{2}{*}{$\frac{\mathrm{Ca}^{2+} \text { concentration }}{\mathrm{mg} / \mathrm{L}}$} & \multirow{2}{*}{$\frac{\text { Water demand }}{\% \mathrm{dw}^{\mathrm{a}}}$} & \multirow{2}{*}{$\frac{\text { Total pore volume }}{\mathrm{cm}^{3} / \mathrm{g}}$} & \multirow{2}{*}{$\frac{\mathrm{MC}}{\% \mathrm{dw}^{\mathrm{a}}}$} \\
\hline & & & & & & & \\
\hline BA1 & 0.56 & 2.44 & 17.44 & 949 & 62.40 & 0.064 & 21 \\
\hline BA2 & 0.56 & 3.70 & 10.23 & 593 & 53.70 & 0.048 & 21 \\
\hline Ss & 0.84 & 2.55 & 34.63 & 465 & 88.80 & 0.098 & 28 \\
\hline CEM I $42.5 \mathrm{~N}$ & 1.08 & 3.17 & 0.96 & - & 20.70 & 0.003 & - \\
\hline
\end{tabular}

a \% dw identifies the rate based on the dry mass of the powder investigated.

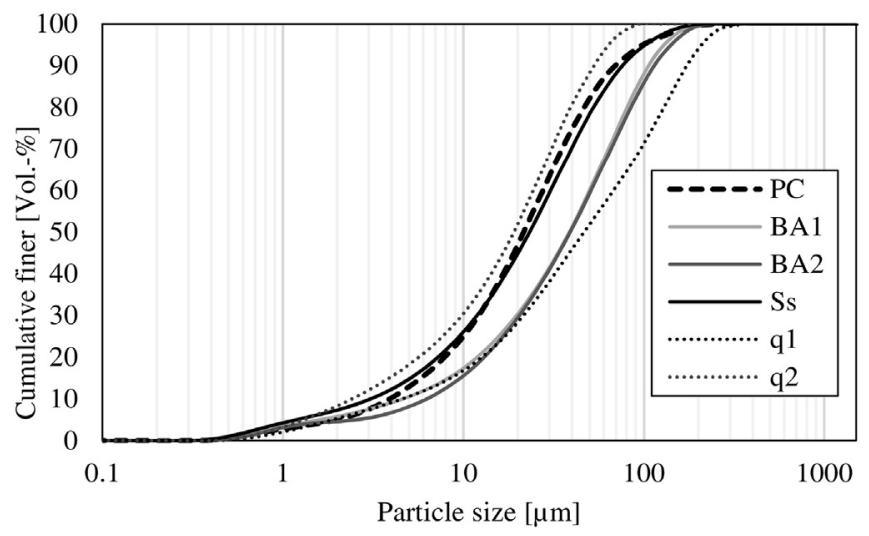

Fig. 2. Cumulative finer as function of the particle size of the by-products Ss, BA1, BA2 (as provided from the incineration plant), reference PC and quartz (q1, q2).

fines taking place during storage leads to the distribution presented as Ss. Despite of this, the PSD of Ss is still finer than BA1 and BA2, but in the range of the PC.

Environmentally, the impact of the pure residues is addressed by comparing the leachates to the limits in the SQD. The reference and measured values are given as appendix. All samples tested far exceed the limits for $\mathrm{Cl}^{-}$and $\mathrm{SO}_{4}^{2-}$, set by the SQD. BA1 is the most contaminated with 12 times the permissible level of sulphates and 16 times the permissible level of $\mathrm{Cl}^{-}$. BA1 and BA2 also contain high levels of copper (13 times and 8 times higher level, respectively), while it exceeds the limit for Ss only by $0.4 \mathrm{mg} / \mathrm{kg}$. Similar in sulphate content to the two references BA, Ss exceeds the permissible level of chlorides 5 times. High concentration of $\mathrm{Sb}$ is mainly registered in Ss, while BA1 and BA2 go beyond the permissible level for Mo and $\mathrm{Cr}$. The lower contamination of the MSWI sludge is caused by the centrifuging process taking place in the plant, leading to the removal of most of the water and leached contaminants.

\subsection{The influence of the mechanical activation on physical properties of MSWI sludge}

The investigation of the influence of MA on the Ss physical properties aims to determine improvement achieved after the application of the treatment, in comparison with references BA1 and BA2. Table 3 illustrates the characteristic diameter sizes of the residues, before and after milling treatment. Starting from the original material, the 30 min grinding affects the fineness of smaller particles, as a reduction is mainly observed for particle diameters smaller than $20 \mu \mathrm{m}$. Longer treatments (60 and $90 \mathrm{~min}$ ) alter the distribution of coarser particles, resulting in $90 \%$ of the material finer than $70 \mu \mathrm{m}$ and $50 \mu \mathrm{m}$, respectively. On the other hand, the minimum diameter dmin is not affected by longer milling times. The different particle size distributions achieved after MA are displayed in Fig. 3. The reduction of PSD is directly linked with the time of treatment: the longer the time, the finer the distribution. However, the effectiveness in the particle size reduction is limited, as a reduction in dmin is not achieved and the shift in PSD usually observed is much greater.

Despite the different materials, Chauruka et al. (2015) also observed this "equilibrium state of milling" during the milling procedure, by using a planetary ball mill. This limited reduction in PSD is attributed to the conversion of the fines produced during grinding in coarser agglomerated particles, joined by van der Waals forces (Chauruka et al., 2015; Filio et al., 1994). During the MA, the fragile zone layer, loosely attached to the BA particles, is compacted and agglomerated with other fines, creating a spherical shape. Fig. 4 shows the particle morphology of MSWI sludge samples after the grinding treatments. For comparison, the untreated MSWI sludge Ss can be visualized in Fig. 1c) (Section 3.1). SEM proves the presence of spherical particles, shaped by the grinding action and result of agglomeration. Fig. 5a) provides an overview of the total pore volume and BET surface area as a function of the grinding time. Among the treated samples, the longer the milling, the lower the total pore volume and surface area. Although decreased, the BET surface area of the treated Ss is higher than the ones of BA1 and BA2.

During the MA, by agglomerating, the dust-like particles reduce the porosity of the BA, resulting in a drop in SSA due to the formation of a more polished and smooth surface (Chauruka et al., 2015). The MA mainly acts on the mesopores (between $2 \mathrm{~nm}$ and $50 \mathrm{~nm}$ ), reducing the pores between 2 and $40 \mathrm{~nm}$ (Fig. 5b). Compared to the BA1 and BA2, the reduction in porosity of treated Ss leads to a total pore volume similar to the reference by-products (between 0.06 and $0.051 \mathrm{~cm}^{3} / \mathrm{g}$ for treated Ss and $0.06-0.048 \mathrm{~cm}^{3} / \mathrm{g}$ for BA1 and BA2, respectively). Table 4 shows the physical features of the treated MSWI sludge, for each milling time. The water demand of Ss 30 , Ss60 and Ss90 is reduced by around $60 \%$, from $88.8 \%$ (Table 2) to about 25-29\% (Table 4). It can be concluded that, after treatment, less water is absorbed and entrapped physically inside the porosity of the particles. An additional evidence of the

Table 3

Characteristic sizes $\left(d_{\min }, d_{10}, d_{50}, d_{90}\right.$ and $\left.d_{\max }\right)$ of the untreated samples and samples milled for different time intervals (30, 60, 90 min).

\begin{tabular}{|c|c|c|c|c|c|c|}
\hline & & $\mathrm{d}_{\min }$ & $\mathrm{d}_{10}$ & $\mathrm{~d}_{50}$ & $\mathrm{~d}_{90}$ & $\mathrm{~d}_{\max }$ \\
\hline Ss & $\mu \mathrm{m}$ & 0.4 & 3.1 & 23.4 & 78.5 & 261.5 \\
\hline Ss30 & $\mu \mathrm{m}$ & 0.4 & 2.8 & 21.8 & 78.2 & 174.1 \\
\hline Ss60 & $\mu \mathrm{m}$ & 0.4 & 1.7 & 17.2 & 70.3 & 174.1 \\
\hline Ss90 & $\mu \mathrm{m}$ & 0.4 & 1.7 & 16.8 & 49.5 & 115.9 \\
\hline
\end{tabular}




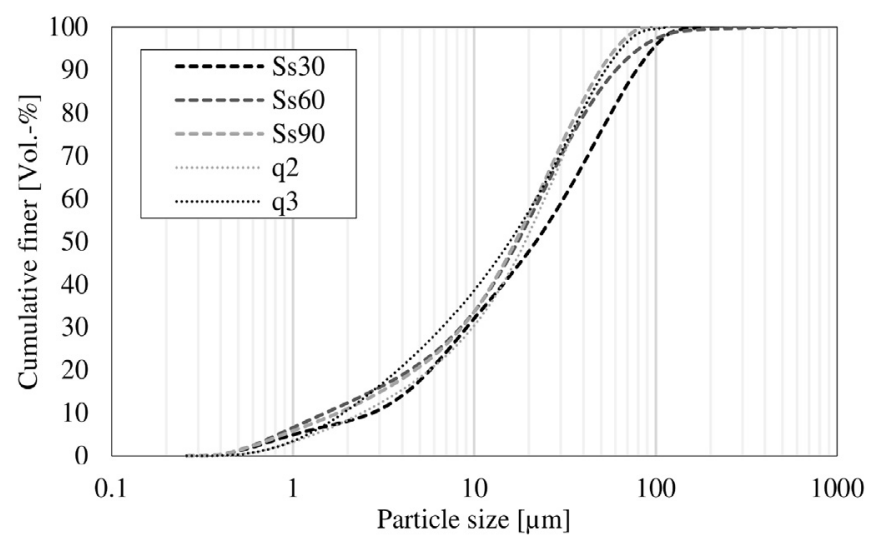

Fig. 3. Cumulative finer of the MSWI sludge after MA at different times, and PSD of reference samples quartz ( $\mathrm{q} 2$ and q3), used to mimic the PSD of treated by-products.

agglomeration phenomena is provided by the increase of bulk density of the powders, testifying an improved packing due to the spherical particle shape obtained after treatment.

\subsection{Evaluation of the pozzolanic activity}

The influence of MA on pozzolanic activity is investigated to evaluate the modification in chemical reactivity after the treatment, for late strength development. Fig. 6a)-c) provides an insight into the pozzolanic activity of the incineration residues, by $\mathrm{CH}$ consumption in time. In general, calcium ions are responsible for
Table 4

Physical properties of the incineration residues after MA.

\begin{tabular}{|c|c|c|c|}
\hline \multirow[t]{2}{*}{ Sample } & Bulk density & Specific gravity & Water demand \\
\hline & $\mathrm{g} / \mathrm{cm}^{3}$ & $\mathrm{~g} / \mathrm{cm}^{3}$ & $\overline{\%}$ \\
\hline Ss30 & 0.97 & 2.44 & 25.4 \\
\hline Ss60 & 1.02 & 2.47 & 29.8 \\
\hline Ss90 & 1.07 & 2.46 & 28.4 \\
\hline
\end{tabular}

a Water demand is expressed by dry mass of the powder.

the aggregation and gelation processes, as they could either (a) react with silicates and aluminates, (b) replace cations within the geo-polymers, or (c) precipitate as $\mathrm{CH}$ (Guo et al., 2010). The carbonation of the free $\mathrm{Ca}^{2+}$ ions is frequently observed after exposition to the ambient conditions. Therefore, for every sample, the total mass is divided by the mass of the residues and the $\mathrm{CH}$ content, as reacted, unreacted and carbonated during the curing time.

After 7 days reaction (Fig. 6a), $\mathrm{SsCH}$ shows the greatest pozzolanic activity (17.6\%) among to the by-products, due to its high surface area available for dissolution (Table 2, Madani et al., 2012). The similar physical properties support the high $\mathrm{CH}$ consumption observed also for the Ss30CH, Ss60CH and Ss90CH (14.3\%, 14.7\% and $16.4 \%$ respectively), within this time frame. Although the pozzolanic activity of $\mathrm{SsCH}$ is fluctuating due to heterogeneity of the sample, increasing rate of the " $\mathrm{CH}$ reacted" is observed at 14 days for every by-product. The milling treatment does not provide additional dissolution of pozzolanic phases within 14 days, as a similar rate of $\mathrm{CH}$ reacted is observed for treated and untreated samples (12.4\% against $14.0 \%, 15.2 \%$ and $17.1 \%$ respectively). This

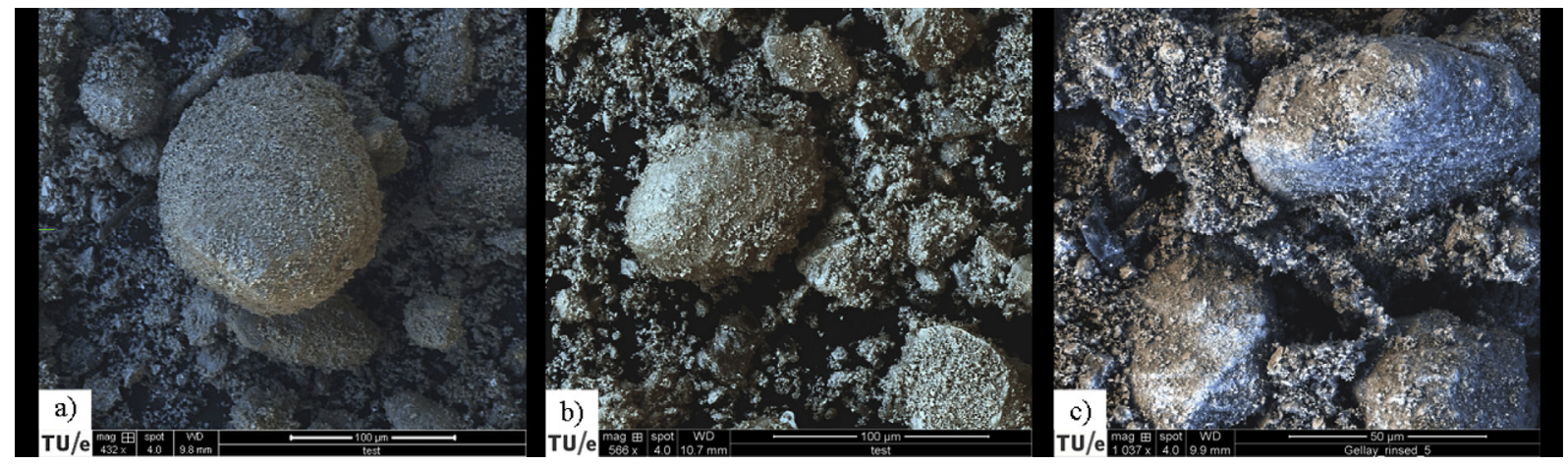

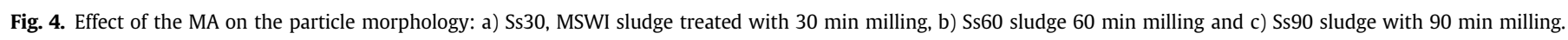

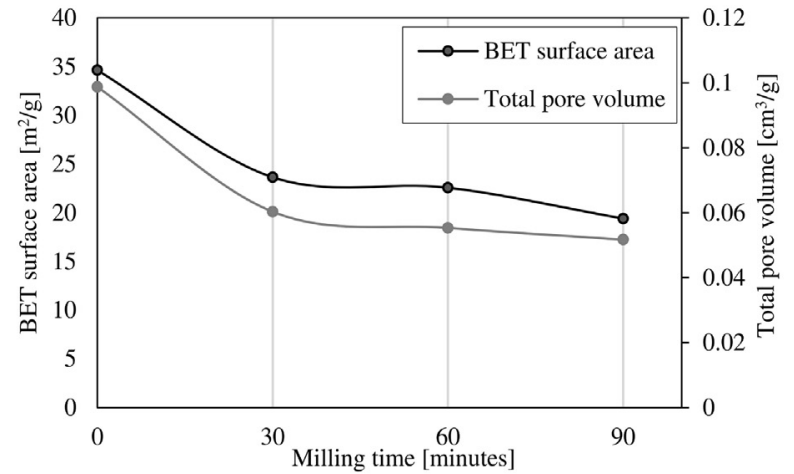

a)

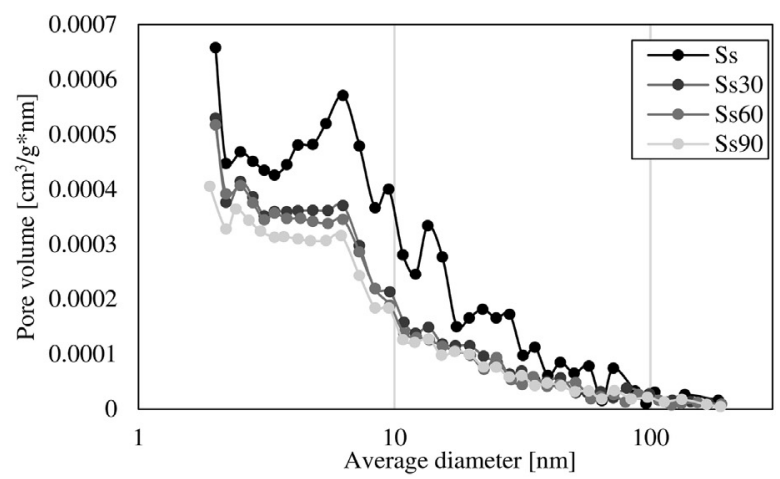

b)

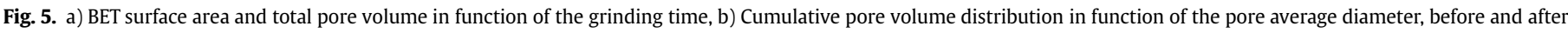
MA. 


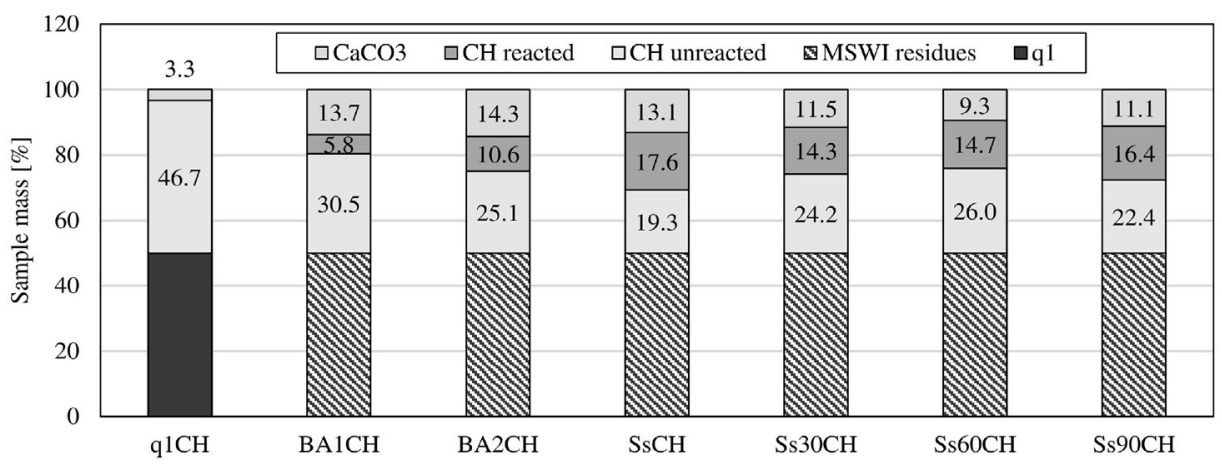

a)

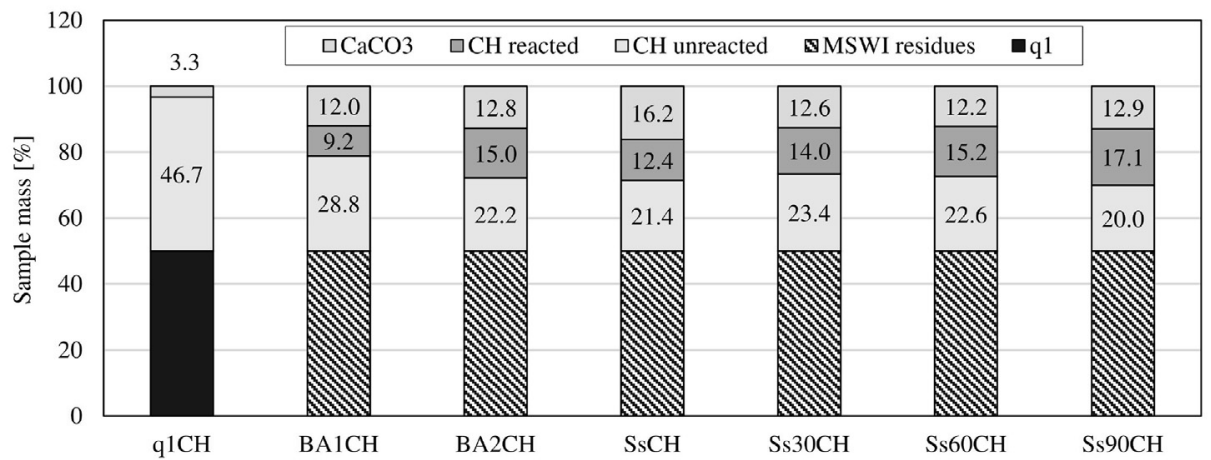

b)

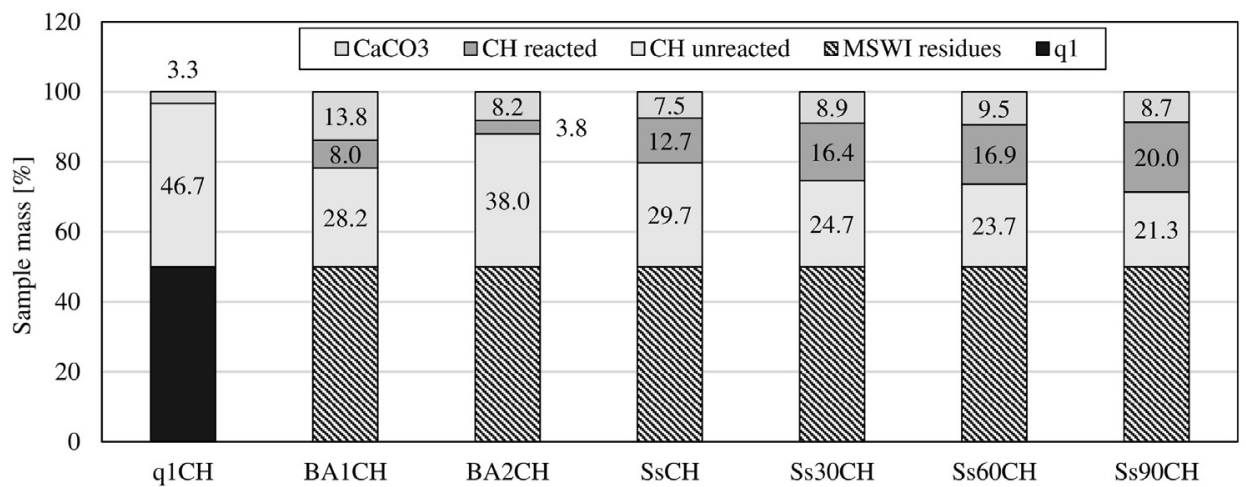

c)

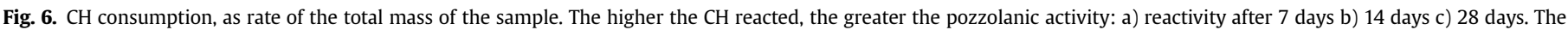

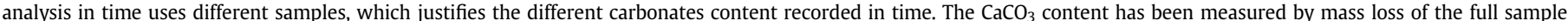

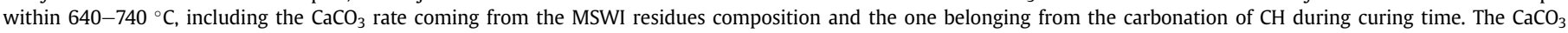

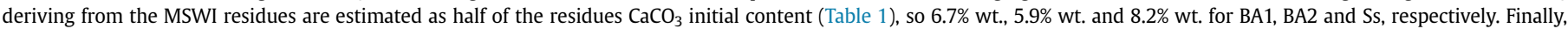
these $\mathrm{CaCO}_{3}$ contents are not included in the quantification of the carbonation rate of the samples (named as " $\mathrm{CaCO}{ }_{3}$ " in $\mathrm{Fig}$. $6 \mathrm{a}$ ) $-\mathrm{c}$ )).

difference is considered within the experimental error. Within 28 days, the " $\mathrm{CH}$ reacted" content in the treated samples is rising, achieving between 16.4 and $20 \%$ of the sample mass. On the other hand, the " $\mathrm{CH}$ reacted" content results decreased in the untreated and reference mixture ( $\mathrm{SsCH}$ and $\mathrm{BA} 2 \mathrm{CH}$ ), leading to an increase of the unreacted $\mathrm{CH}$ content by $8.3 \%$ and $15.8 \%$ respectively, compared to 14 days results. It appears that the decreasing concentration of pozzolan leads to the saturation of the solution with respect to $\mathrm{CH}$ and its consequent precipitation. Although it requires specific conditions, the precipitation of $\mathrm{CH}$ is a phenomenon taking place also during PC hydration. It takes place at a $\mathrm{pH}$ of $12.5-12.8$ (Mohammadi et al., 2012) and it occurs in the matrix porosity, 
when the saturation with respect of $\mathrm{Ca}^{2+}$ is reached in the pore solution. The ions concentration to generate a saturated $\mathrm{Ca}^{2+}$ solution is indicated to be around $22 \mathrm{mmol} / \mathrm{L}$ (Bullard, 2008). In the analysed system, the presence of those conditions can also occur. Although $\mathrm{CH}$ is usually considered as a weak base, MWSI byproducts are able to rise $\mathrm{pH}$ of water, due to the dissolution of alkalis like $\mathrm{Na}^{+}$or $\mathrm{K}^{+}$(Ahn et al., 2007). Therefore, both $\mathrm{CH}$ and MSWI residues contribute to the creation of the alkaline environment, suitable for the $\mathrm{CH}$ precipitation. Moreover, the presence of soluble $\mathrm{Ca}^{2+}$ species dissolved from BA1, BA2 and Ss favours the achievement of the optimum concentration for the $\mathrm{CH}$ precipitation (Table 2), while their high porosity of the by-products favours the formation of pores within the matrix. The precipitation of $\mathrm{CH}$ has the negative effect of lowering the $\mathrm{pH}$ of the alkaline solution, due to the removal of $\mathrm{OH}^{-}$ions, which will compromise the further dissolution and precipitation process (Millogo et al., 2012; van Deventer et al., 2007). On the other hand, Ss30CH, Ss60CH and Ss90CH limit the $\mathrm{CH}$ precipitation within 28 days, underlining the continuation of a slow pozzolanic activity. Compared to the untreated system $\mathrm{SsCH}$, the $\mathrm{CH}$ reacted increases by $3.7 \%, 4.2 \%$ and $7.3 \%$ depending on the milling time. To conclude, the MA leads to a small improved pozzolanic activity after 28 days, due to the continuation of the $\mathrm{CH}$ consumption, and thus pozzolanic activity, in time.

\subsection{Influence of by-products in cementitious systems}

In addition to the pozzolanic activity, the evaluation of the contribution of the residues in early stage reaction is performed in the presence of PC. Fig. 7a) describes the cumulative heat released by the pure MSWI residues in the presence of water. Although without the presence of any alkali activator or a hydraulic binder, all the by-products register a minimal heat development, due to the dissolution of ions in contact with water. BA1 and BA2 results in a greater cumulative heat released within 5 days, compared to Ss. Due to the wet separation treatment of Ss, the presence of soluble species is reduced, leading to the lower cumulative heat registered within 5 days. This phenomenon underlines a possible contribution to the hydration of $\mathrm{PC}$, due to dissolution of reactive phases, previously described in Section 2.2.4. Fig. 7b) shows the cumulative heat for the blended pastes and the reference samples containing pure $\mathrm{PC}$ or $\mathrm{PC}$ and inert quartz to emulate the nucleation sites contributions (PC, q1PC, q2PC and q3PC). The mixtures including quartz prove the presence of the heterogeneous nucleation effect, increasing the intensity of the heat released at 5 days $\left(Q_{n u c l}\right.$ in Formula (1)). Due to the catalysis of the reaction products around

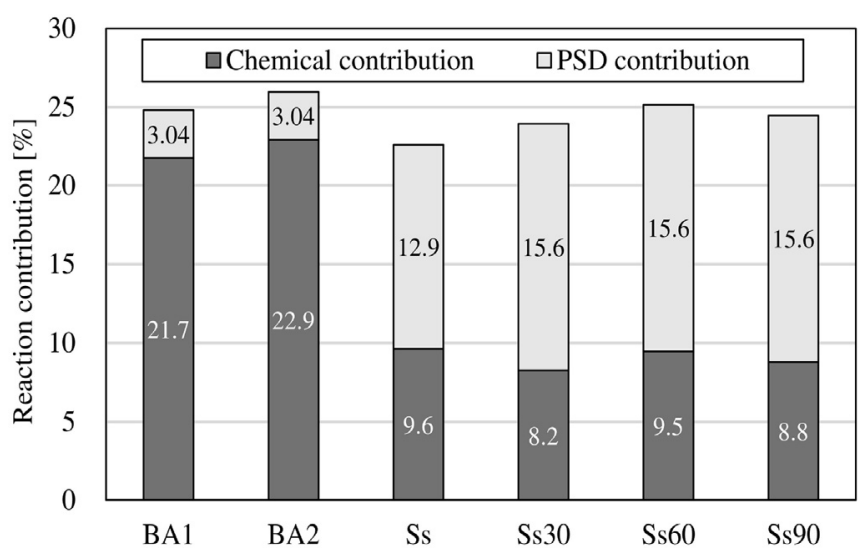

Fig. 8. Contribution to the reaction degree of MSWI by-products, depending on the PSD and chemical dissolution, at 5 days (Formula (1) and (2)).

the new nuclei, the presence of additional active sites acts also on the chemistry of the PC hydration (Cyr et al., 2005). Moreover, the presence of MSWI residues has an influence on the main reaction of $\mathrm{PC}$, due to the dissolution of additional species unrelated to the standard PC reaction $\left(Q_{\text {diss }}\right.$ in Formula (2)).

Fig. 8 displays the contributions of nucleation sites $\left(Q_{\text {nucl }}\right)$ and of the dissolution of phases ( $Q_{\text {diss }}$ ) from BA, calculated by formulas (1) and (2). These contributions are expressed as rate of the reference reaction degree. Although all the powders are ranging between 0.04 and $0.250 \mathrm{~mm}$, the contribution provided by the heterogeneous nucleation increases with the content of fines. Despite the finer PSD, Ss results in a total lower contribution in the hydration degree compared to BA1 and BA2 (22.6\% compared to $24.8 \%$ and $26 \%$, respectively). These data underline the greater amount of phases available for dissolution at early stages in BA1 and BA2. The presence of a reduced amount of soluble phases in Ss is mainly due to the wet treatment that it undergoes during the upgrade of BAC (4-32 mm). The MA seems minimally beneficial for the improvement of the reaction degree of the PC, due to the small increase of heterogeneous nucleation sites.

The contribution due to this factor increases the hydration degree from $12 \%$ to $15 \%$, while the contribution caused by the dissolution of ions is constant independently form the MA, leading to a final enhancement of hydration degree of SsPC by $2-3 \%$, depending on the treatment. This increment, within the experimental error, cannot be taken into account as a clear evidence of the improvement of early reaction degree after the MA. Summing the two

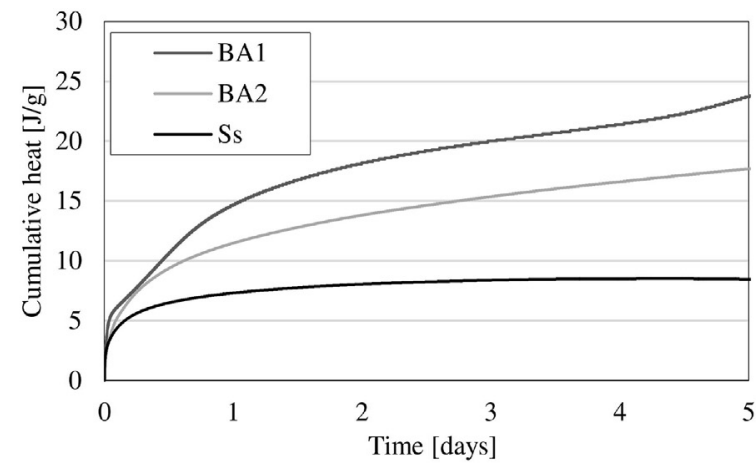

a)

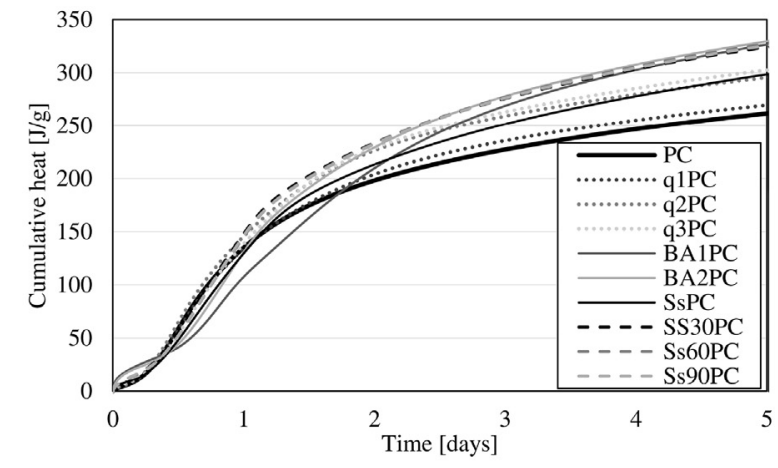

b)

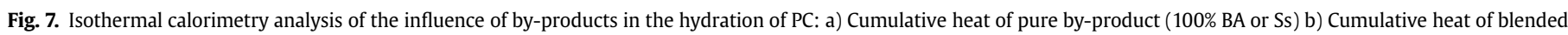
cement (25\% by-products $75 \%$ PC), 25\% quartz $75 \%$ PC and 100\% PC, within 5 days. 
contributions, the treated samples increases the hydration degree of PC by $23.8 \%, 25.1 \%$ and $24.4 \%$ depending on the milling time. As shown from calorimetry results, by increasing the heterogeneous nucleation effect, the early hydration degree is mainly affected. However, the enhancement of early hydration of PC does not necessarily correspond to the increase of the final early strength of mortars, as the latter depends on both chemical and physical properties of the MSWI residues.

\subsection{Evaluation of mechanical performances of the blended cements}

Based on the results of the characterization and reactivity analysis, the performances of MSWI residues as cement replacement are tested. Fig. 9a) illustrates the average slump diameter of the treated and untreated residues, replacing $25 \%$ of the $\mathrm{PC}$, by mass. In the case of both BA1 and BA2, the replacement of $25 \%$ of untreated by-products does not seem to affect the rheological behaviour of the paste. Their reduced total pore volume, and thus water demand, and the coarser PSD compared to Ss (Table 2), explain the less viscous behaviour, detected in Fig. 9. On the other hand, the replacement of untreated Ss reduces the slump flow diameter by $8 \%$, compared to the reference PC. Differently to BA1 and BA2, the total pore volume and surface area of Ss result in a high water absorption, entrapping part of the water necessary for reaction by capillary suction. The grinding treatment is beneficial, since, increasing the slump flow diameter by $20-40 \%$, it allows for a better distribution and compaction of the paste. Fig. 9b) describes the mechanical performances of the mortars, based on the same mixtures. The lower porosity of BA2 (Table 2) allows a proper distribution of the paste and an enhanced mechanical performance within 14 days, compared to BA1PC and SsPC.

By replacing cement with Ss, its finer PSD is expected to provide higher density mortars due to a better packing of the particles. However, the excessive water demand leads to a high viscosity of the paste, which limits its distribution and causes an inadequate compaction of the mortars and low strength. As also discussed in Section 3.4, in the mortars based on treated MSWI sludge (Ss30PC, Ss60PC and Ss90PC), the finer PSD provides additional heterogeneous nucleation sites, favouring the increase in the hydration degree of the paste (15.6\% higher degree of reaction at 5 days). The limited water absorption of treated Ss enhances the homogeneous distribution of the paste into the moulds and increases the water available for reaction. Moreover, the formation of round particles during the treatment facilitates the formation of the so called "ball bearing effect", providing a beneficial influence in the compaction behaviour and the final packing fraction obtained (Hüsken and
Table 5

Strength activity index (SAI) for untreated and treated residues as partial replacement of cement, at different times. The determination of SAI is based on Formula (3).

\begin{tabular}{llll}
\hline \multicolumn{2}{l}{ Strength Activity Index } & & \\
\hline Time & 7 days & 14 days & 28 days \\
\hline SsPC & \pm 0.29 & \pm 0.81 & \pm 0.63 \\
BA1PC & \pm 0.93 & \pm 0.86 & \pm 0.69 \\
BA2PC & \pm 0.83 & \pm 1.08 & \pm 0.71 \\
Ss30PC & \pm 0.56 & \pm 0.74 & \pm 0.93 \\
Ss60PC & \pm 0.86 & \pm 0.85 & \pm 0.91 \\
Ss90PC & \pm 0.75 & \pm 0.77 & \pm 0.89 \\
\hline
\end{tabular}

Brouwers, 2012). Favoured by their higher pozzolanic activity, Ss30PC and Ss60PC have 32\% higher compressive strength, after 28 days compared to the untreated sample. In Ss90PC mixture, the L/S ratio applied results in an high slump flow, leading to the formation of additional capillary pores (Kumar and Bhattacharjee, 2003) and causing a reduction in the mechanical performances compared to Ss60 and Ss30, at any age.

Finally, independently from the milling time, the treated MSWI sludge outperforms the BA1PC and BA2PC after 28 days, with Ss30PC exceeding the compressive strength after 28 days, by $25 \%$ for BA1PC and 23\% for BA2PC. Table 5 shows the SAI concerning the treated and untreated MSWI sludge and by-products. BA1PC and BA2PC are able to fulfil the requirement for strength after 7 and 14 days, but not after 28. For both mixtures, the increase in SAI is not linear, but shows fluctuations, with a maximum after 14 days. A similarly variable trend is seen with the untreated MSWI sludge, while the SAI is satisfied for Ss60PC and Ss90PC at any time. Among the treated samples, Ss60PC leads to the most steady and high results. The achieved improvement is not only linked to the influence of chemical reactivity (Section 3.3 and 3.4) but mainly to an optimisation of packing and reduction of total porosity (Section 3.2).

\subsection{Leaching behaviour}

In order to evaluate the immobilization properties of the PC mixtures, leaching tests are performed on the mortars as described in Section 2.2.6. This analysis is performed on reference, untreated material and on the treated one, after 28 days curing and displayed in Table 6. In the presence of cement the leaching of contaminants is reduced, fulfilling the requirements for $\mathrm{Cl}^{-}$and $\mathrm{SO}_{4}^{2-}$, out of range in the pure material leaching (Section 3.1). Independently from the treatment, the MA is inconsequential to the leaching properties of the blended pastes, since it does not differ from the untreated

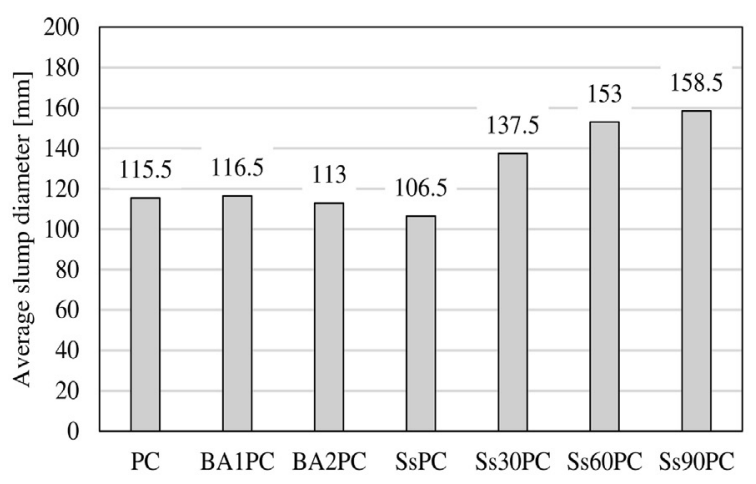

a)

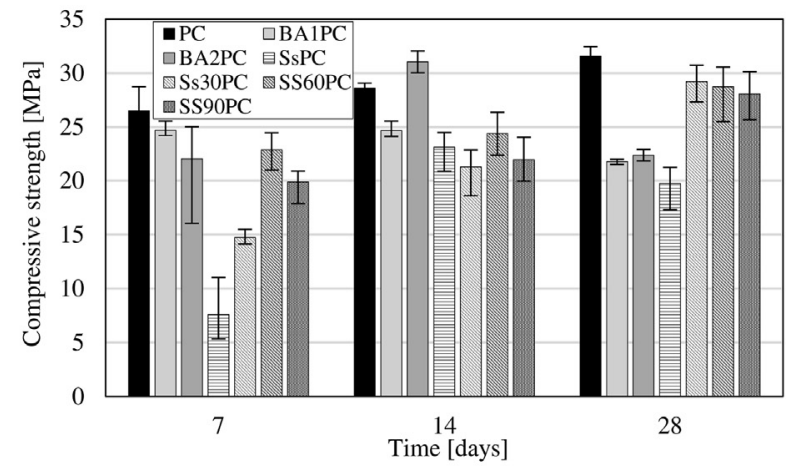

b)

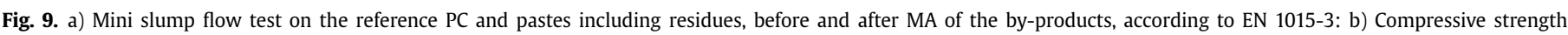
evaluation of blended pastes, characterized by $25 \%$ MSWI residues and $75 \%$ PC and reference PC. 
Table 6

Leaching of inorganic contaminants measured by one stage batch leaching test (EN 12457-2) and comparison with the legislation limits (“Soil Quality Decree,” 2015).

\begin{tabular}{|c|c|c|c|c|c|c|c|}
\hline \multirow[t]{2}{*}{ Parameter } & \multirow{2}{*}{$\frac{\text { Unshaped material (SQD) }}{\mathrm{mg} / \mathrm{kg} \text { d.s. }}$} & \multirow{2}{*}{$\frac{\mathrm{BA} 1 \mathrm{PC}}{\mathrm{mg} / \mathrm{kg} \text { d.s. }}$} & \multirow{2}{*}{$\frac{\mathrm{BA} 2 \mathrm{PC}}{\mathrm{mg} / \mathrm{kg} \text { d.s. }}$} & \multirow{2}{*}{$\frac{\mathrm{SsPC}}{\mathrm{mg} / \mathrm{kg} \mathrm{d.s.}}$} & \multirow{2}{*}{$\frac{\mathrm{Ss} 30 \mathrm{PC}}{\mathrm{mg} / \mathrm{kg} \text { d.s. }}$} & \multirow{2}{*}{$\frac{\mathrm{Ss} 60 \mathrm{PC}}{\mathrm{mg} / \mathrm{kg} \text { d.s. }}$} & \multirow{2}{*}{$\frac{\mathrm{Ss} 90 \mathrm{PC}}{\mathrm{mg} / \mathrm{kg} \text { d.s. }}$} \\
\hline & & & & & & & \\
\hline Antimony (Sb) & 0.32 & $<0.1$ & $<0.1$ & $<0.1$ & $<0.1$ & $<0.1$ & $<0.1$ \\
\hline Arsenic (As) & 0.90 & $<0.3$ & $<0.3$ & $<0.3$ & $<0.03$ & $<0.3$ & $<0.3$ \\
\hline Barium (Ba) & 22.00 & 16.0 & 17.1 & 13.4 & 14.6 & 10.5 & 13.6 \\
\hline Cadmium (Cd) & 0.04 & $<0.02$ & $<0.02$ & $<0.02$ & $<0.02$ & $<0.02$ & $<0.02$ \\
\hline Chromium (Cr) & 0.63 & 0.4 & 0.4 & 0.3 & 0.4 & 0.4 & 0.3 \\
\hline Cobalt (Co) & 0.54 & $<0.02$ & $<0.02$ & $<0.02$ & $<0.02$ & $<0.02$ & $<0.02$ \\
\hline Coper $(\mathrm{Cu})$ & 0.90 & 0.3 & 0.3 & 0.3 & 0.3 & 0.3 & 0.4 \\
\hline Lead $(\mathrm{Pb})$ & 2.30 & $<0.1$ & $<0.1$ & $<0.1$ & $<0.1$ & $<0.1$ & $<0.1$ \\
\hline Molybdenum (Mo) & 1.00 & 0.2 & 0.16 & 0.15 & 0.14 & 0.14 & 0.14 \\
\hline Nickel (Ni) & 0.44 & $<0.05$ & $<0.05$ & $<0.05$ & $<0.05$ & $<0.05$ & $<0.05$ \\
\hline Selenium (Se) & 0.15 & $<0.2$ & $<0.2$ & $<0.2$ & $<0.2$ & $<0.2$ & $<0.2$ \\
\hline $\operatorname{Tin}(\mathrm{Sn})$ & 0.40 & $<0.1$ & $<0.1$ & $<0.1$ & $<0.1$ & $<0.1$ & $<0.1$ \\
\hline Vanadium (V) & 1.80 & $<0.1$ & $<0.1$ & $<0.1$ & $<0.1$ & $<0.1$ & $<0.1$ \\
\hline Zinc $(Z n)$ & 4.50 & 0.1 & 0.2 & 0.06 & $<0.05$ & 0.1 & $<0.05$ \\
\hline Chloride $(\mathrm{Cl})$ & 616 & 511.57 & 492.16 & 136.26 & 122.26 & 115.09 & 108.02 \\
\hline Sulphate $\left(\mathrm{SO}_{4}^{2-}\right)$ & 1730 & 40.10 & 40.37 & 35.75 & 40.28 & 43.78 & 39.36 \\
\hline
\end{tabular}

material. In the presence of $\mathrm{PC}$, the retention rate for chlorides ranges between $88 \%$ wt. (BA1) and $77 \%$ wt. (Ss30 and Ss60). For $\mathrm{SO}_{4}^{2-}$ the value is around $99 \%$, independently from the type of residue applied. The retention rate of $\mathrm{Cu}$ varies around $80 \% \mathrm{wt}$. for the references and $7.6 \%$ wt. for Ss, while for Mo it is around $60 \%$ wt. for references and 20\% wt. for Ss. Furthermore, Sb levels are within the reference values, with retention rate of $66 \%$ wt. for BA1 and $83 \%$ wt. for Ss. The low concentration of $\mathrm{Cr}$ is owed to the dilution effect, created by replacing $25 \%$ wt. of the binder. In conclusion, all the contaminants are below the reference values, respecting the SQD legislation for unshaped materials ("Soil Quality Decree," 2015), and ensuring environmentally the application of MSWI sludge as secondary building material.

\section{Summary and conclusions}

This study evaluates the behaviour of MSWI sludge (Ss), a waste stream created by the washing treatment of coarse MSWI bottom ash (BAc). Because of its reduced availability of soluble phases (due to wet treatments) and the porous and irregular morphology of its particles, Ss is not widely studied as building material. However, the PSD and chemical composition of the MSWI sludge are similar to BA fines $(0.04 \mathrm{~mm}-0.250 \mathrm{~mm})$, often applied in construction field. Therefore, to address in environmental impact of Ss, two BA streams (BA1 and BA2) are used as reference in combination with Portland cement (PC). An enhancement of the properties of Ss is provided by dry mechanical activation (MA) at different durations (30, 60, $90 \mathrm{~min})$. The following conclusions are drawn:

1. The MA treatment has a beneficial effect on the physical properties of the MSWI sludge. The applied milling treatment reduces the total pore volume of the powder, and thus its water demand. After the treatment, a reduction of the surface area is registered due to fines agglomerating in spherical particles.

2. Chemically, the pozzolanic activity within 14 days is slightly affected by the MA of Ss. However, while the precipitation of $\mathrm{CH}$ over time in the untreated samples is observed, treated MSWI sludge continues to react, increasing the pozzolanic activity in time, up to a maximum of $7.3 \%$.

3. The replacement of the tested by-products results in a contribution of the final PC hydration degree, independently on the treatment. After the MA treatment of Ss, the small increase ( $\approx 3 \%$ ) due to the heterogeneous nucleation contribution does not ensure the efficacy of the treatment, for the further enhancement of the hydration degree of the paste.

4. By the reduction of total pore volume and due to the enhanced packing, the mechanical treatment affects the rheological behaviour of the pastes. Due to a better distribution and compaction of mortars pastes, the MA of Ss allows the improvement in mechanical strength by $\approx 32 \%$ compared to the untreated material and by $\approx 25 \%$ compared to the other references BA1PC and BA2PC. The SAI is satisfied in time for both Ss60 and Ss90.

5. Environmentally, for all the samples (including reference) the leaching of all contaminants is below the legal limit, including $\mathrm{Cl}^{-}$and $\mathrm{SO}_{4}^{2-}$. For the MA treated samples, the retention rate is $\approx 77 \%$ for the chlorides, $\approx 99 \%$ for the sulphates and $\approx 83 \%$ for antimony.

The results of MA treatment underline the possible use of MSWI sludge as secondary building material, both mechanically and environmentally. In order to optimize the treatment and application, further research will include the analysis of higher replacements of PC with MSWI sludge, to find the maximum substitution level, which satisfy the requirements of strength and leaching behaviour. The same treatment will be applied to BA1 and BA2 to improve the final mechanical behaviour and fulfil the SAI threshold.

\section{Acknowledgments}

The authors would like to acknowledge financial support provided by STW (Stichting voor de Technische Wetenschappen), the Netherlands, under the project number 10019729: "Environmental concrete based on treated MSWI bottom ash". Moreover, for equipment support the authors would like to acknowledge ESEM in the Multi-Scale laboratory of the group Mechanics of Materials, Mechanical Engineering, and the group Chemical Engineering and Chemistry, Chemical Reactor Engineering, Eindhoven University of Technology. Furthermore, the authors wish to express their gratitude to the following sponsors of the Building Materials research group at TU Eindhoven: Rijkswaterstaat Grote Projecten en Onderhoud; Graniet-Import Benelux; Kijlstra Betonmortel; Struyk Verwo; Attero; Enci; Rijkswaterstaat Zee en Delta-District Noord; Van Gansewinkel Minerals; BTE; V.d. Bosch Beton; Selor; GMB; Geochem Research; Icopal; BN International; Eltomation; Knauf Gips; Hess AAC Systems; Kronos; Joma; CRH Europe Sustainable Concrete Centre; Cement \& Beton Centrum; Heros and Inashco (in chronological order of joining). 


\section{Appendix A. Supplementary data}

Supplementary data related to this article can be found at http:// dx.doi.org/10.1016/j.jenvman.2017.05.024.

\section{References}

Abdel-Kader, Noha H., Shahin, Reda R., Khater, Hasan A., 2013. Assessment of heavy metals immobilization in artificially contaminated soils using some local amendments. Open J. Metal. 03 (02), 68-76. http://dx.doi.org/10.4236/ ojmetal.2013.32a1009.

Ahn, J.-W., Cho, H.-C., You, K.-S., Han, G.-C., Um, N.-I., 2007. Characteristic of carbonation reaction from municipal solid waste incinerator bottom ash as a function of water content and their effect on the stabilization of copper and lead. In: Materials Science Forum, vol. 544-545, pp. 533-536. http://dx.doi.org/ 10.4028/www.scientific.net/MSF.544-545.533.

Alam, O. Schollbach, K. Florea, M.V.A., Brouwers, H.J.H., 2016. Investigating washing treatment to minimize leaching of chlorides and heavy metals from MSWI bottom ash. In: 4th International Conference on Sustainable Solid Waste Management. Limassol, Cyprus.

Allegrini, Elisa, Vadenbo, Carl, Boldrin, Alessio, Astrup, Thomas Fruergaard, 2015. Life cycle assessment of resource recovery from municipal solid waste incineration bottom ash. J. Environ. Manag. 151, 132-143. http://dx.doi.org/10.1016/ j.jenvman.2014.11.032.

Bertolini, Luca, Carsana, Maddalena, Cassago, Davide, Quadrio Curzio, Alessandro Collepardi, Mario, 2004. MSWI ashes as mineral additions in concrete. Cem. Concr. Res. 34 (10), 1899-1906. http://dx.doi.org/10.1016/j.cemconres.2004.02.001.

Biganzoli, L., 2012. Aluminium Recovery from MSWI Bottom Ash. Politecnico di Milano, Department of civil and environmental engineering.

Boesten, E.P.M., (Ellen), Bianchi, G.Q., Brouwers, H.J.H., 2012. Influence of Alternative Raw Material on Autoclaved Aerated Concrete.

Bullard, J.W., 2008. A reaction-diffusion model for simulating 3-D microstructure development of cement paste. In: Proc. ConMod '08 Int. RILEM Symp. Concr. Model, pp. 377-384.

Chauruka, S.R., Hassanpour, A., Brydson, R., Roberts, K.J., Ghadiri, M., Stitt, H., 2015. Effect of mill type on the size reduction and phase transformation of gamma alumina. Chem. Eng. Sci. 134, 774-783. http://dx.doi.org/10.1016/j.ces.2015.06.004.

Cheriaf, M., Rocha, J.Cavalcante, Péra, J., 1999. Pozzolanic properties of pulverized coal combustion bottom ash. Cem. Concr. Res. 29 (9), 1387-1391. http:/ dx.doi.org/10.1016/s0008-8846(99)00098-8.

Cyr, Martin, Lawrence, Philippe, Ringot, Erick, 2005. Mineral admixtures in mortars. Cem. Concr. Res. 35 (4), 719-730. http://dx.doi.org/10.1016 j.cemconres.2004.05.030.

EN 1015-3, 2007. Method for Testing Mortars for Masonry - Part 3: Determination of Consistency of Fresh Mortars (By Flow Table).

EN 196-1, 2005. Method for Testing Cement - Part 1: Determination of Strength.

Fernández-Jiménez, A., Palomo, A., 2003. Characterisation of fly ashes. Potential reactivity as alkaline cements 10.1016/s0016-2361(03)00194-7.

Filio, James M., Sugiyama, Kazumasa, Saito, Fumio, Waseda, Yoshio, 1994. A study on talc ground by tumbling and planetary ball mills. Powder Technol. 78 (2) 121-127. http://dx.doi.org/10.1016/0032-5910(93)02775-6.

Florea, M.V.A., 2016. Environmental interactions of cement-based products. In: Int. Conf. Adv. Cem. Concr. Technol.. Africa, Dar es Salaam, Tanzania, accepted in October 2015.

Florea, M.V.A., Doudart de la Grée, G.C.H., Keulen, A., Brouwers, H.J.H., 2015. Contaminated biomass fly ashes - characterization and treatment optimization for reuse as building materials. Waste Manag. 49, 96-109. http://dx.doi.org 10.1016/j.wasman.2015.12.023.

Forteza, R., Far, M., Seguí, C., Cerdá, V., 2004. Characterization of bottom ash in municipal solid waste incinerators for its use in road base. Waste Manag. (New York, N.Y.) 24 (9), 899-909. http://dx.doi.org/10.1016/j.wasman.2004.07.004.

Gabrovšek, R., Vuk, T., Kaučič, V., 2006. Evaluation of the hydration of Portland cement containing various carbonates by means of thermal analysis. Acta Chim. Slov. 53, 159-165.

Guo, X., Shi, H., Chen, L., Dick, W.A., 2010. Alkali-activated complex binders from class C fly ash and Ca-containing admixtures. J. Hazard. Mater. 173 (1-3), 480-486. http://dx.doi.org/10.1016/j.jhazmat.2009.08.110.

Hela, Rudolf, Orsáková, Denisa, 2013. The mechanical activation of fly ash. Proced. Eng. 65, 87-93. http://dx.doi.org/10.1016/j.proeng.2013.09.016.

Hernández-Montoya, V., García-Servin, J., Bueno-López, J.I., 2012. Thermal treatments and activation procedures used in the preparation of activated carbons. Lignocellul. Precursors Used Synth. Act. Carbon - Charact. Tech. Appl. Wastewater Treat. 19-36. http://dx.doi.org/10.5772/39365.

Hjelmar, Ole, 1996. Disposal strategies for municipal solid waste incineration residues. J. Hazard. Mater. 47 (1-3), 345-368. http://dx.doi.org/10.1016/03043894(95)00111-5.

Holm, J., Hansen, J.B., 2003. CEN EN 12457 Leaching Test: Comparison of Test Results Obtained by Part 1 and 2 with Test Results Obtained by Part 3 Dorthe Lærke Baun Jesper Holm Jette Bjerre Hansen Margareta Wahlström.
Hunger, M., Brouwers, H.J.H., 2009. Flow analysis of water-powder mixtures: application to specific surface area and shape factor. Cem. Concr. Compos. 31 (1), 39-59. http://dx.doi.org/10.1016/j.cemconcomp.2008.09.010.

Hüsken, G., Brouwers, H.J.H., 2012. On the early-age behavior of zero-slump concrete. Cem. Concr. Res. 42 (3), 501-510. http://dx.doi.org/10.1016/ j.cemconres.2011.11.007.

Inkaew, K., Saffarzadeh, A., Shimaoka, T., 2014. Characterization of grate sifting deposition ash, unquenched bottom ash and water-quenched bottom ash from mass-burn moving grate waste to energy plant. J. Jpn. Soc. Civ. Eng. Ser. G. Environ. Res. 70, III_469-III_475. http://dx.doi.org/10.2208/jscejer.70.III_469.

Keulen, A., Florea, M.V.A., Brouwers, H.J.H., 2012. Upgrading MSWI bottom ash as building material for concrete mixes. In: Proc. 18th Int. Conf. Build. Mater. (Ibausil), Weimar, pp. 545-553.

Kula, I., Olgun, A., Sevinc, V., Erdogan, Y., 2002. An investigation on the use of tincal ore waste, fly ash, and coal bottom ash as Portland cement replacement materials. Cem. Concr. Res. 32 (2), 227-232. http://dx.doi.org/10.1016/s00088846(01)00661-5.

Kumar, Rakesh, Bhattacharjee, B., 2003. Porosity, pore size distribution and in situ strength of concrete. Cem. Concr. Res. 33 (1), 155-164. http://dx.doi.org/ 10.1016/s0008-8846(02)00942-0.

Kumar, Sanjay, Kumar, Rakesh, 2011. Mechanical activation of fly ash: effect on reaction, structure and properties of resulting geopolymer. Ceram. Int. 37 (2), 533-541. http://dx.doi.org/10.1016/j.ceramint.2010.09.038.

Lam, Charles H.K., Ip, Alvin W.M., Barford, John Patrick, McKay, Gordon, 2010. Use of incineration MSW ash: a review. Sustainability 2 (7), 1943-1968. http:// dx.doi.org/10.3390/su2071943.

Lin, C.L., Weng, M.C., Chang, C.H., 2012. Effect of incinerator bottom-ash composition on the mechanical behavior of backfill material. J. Environ. Manag. 113, 377-382. http://dx.doi.org/10.1016/j.jenvman.2012.09.013.

Lothenbach, B., Scrivener, K., Hooton, R.D., 2010. Cement and concrete research supplementary cementitious materials. Cem. Concr. Res. 1-13. http:// dx.doi.org/10.1016/j.cemconres.2010.12.001.

Madani, Hesam, Bagheri, Alireza, Parhizkar, Tayebeh, 2012. The pozzolanic reactivity of monodispersed nanosilica hydrosols and their influence on the hydration characteristics of Portland cement. Cem. Concr. Res. 42 (12), 1563-1570. http://dx.doi.org/10.1016/j.cemconres.2012.09.004.

Millogo, Younoussa, Morel, Jean-Claude, Traoré, Karfa, Ouedraogo, Raguilnaba, 2012. Microstructure, geotechnical and mechanical characteristics of quicklimelateritic gravels mixtures used in road construction. Constr. Build. Mater. 26 (1), 663-669. http://dx.doi.org/10.1016/j.conbuildmat.2011.06.069.

Mohammadi, Z., Shalavi, S., Yazdizadeh, M., 2012. Antimicrobial activity of calcium hydroxide in endodontics: a review. Chonnam Med. J. 48 (3), 133-140. http:// dx.doi.org/10.4068/cmj.2012.48.3.133.

NEN-EN 6966, 2005. Milieu - Analyse van geselecteerde elementen in water eluaten en destruaten - Atomaire emissiespectrometrie met inductief gekoppeld plasma (The Netherlands).

Onori, R., Polettini, A., 2011. Alkaline Activation of Incinerator Bottom Ash for Use in Structural Applications. Sapienza, Universita' di Roma.

Onori, Roberta, Polettini, Alessandra, Pomi, Raffaella, 2011. Mechanical properties and leaching modeling of activated incinerator bottom ash in Portland cement blends. Waste Manag. 31 (2), 298-310. http://dx.doi.org/10.1016/ j.wasman.2010.05.021.

Polettini, A., Pomi, R., Fortuna, E., 2009. Chemical activation in view of MSWI bottom ash recycling in cement-based systems. J. Hazard. Mater. $162(2-3)$ 1292-1299. http://dx.doi.org/10.1016/j.jhazmat.2008.06.018.

Porciúncula, C.B., Marcilio, N.R., Tessaro, I.C., Gerchmann, M., 2012. Production of hydrogen in the reaction between aluminum and water in the presence of $\mathrm{NaOH}$ and $\mathrm{KOH}$. Braz. J. Chem. Eng. 29 (2), 337-348. http://dx.doi.org/10.1590/ s0104-66322012000200014.

Qiao, X.C., Cheeseman, C.R., Poon, C.S., 2009. Influences of chemical activators on incinerator bottom ash. Waste Manag. (New York, N.Y.) 29 (2), 544-549. http:// dx.doi.org/10.1016/j.wasman.2008.06.026.

Qiao, X.C., Tyrer, M., Poon, C.S., Cheeseman, C.R., 2008. Characterization of alkaliactivated thermally treated incinerator bottom ash. Waste Manag. (New York, N.Y.) 28 (10), 1955-1962. http://dx.doi.org/10.1016/j.wasman.2007.09.007.

Revathi, V., Thaarrini, J., Rao, M.V., 2014. A Prospective Study on Alkali Activated Bottom Ash-GGBS Blend in Paver Blocks, vol. 8, pp. 290-297.

Sabbas, T., Polettini, A., Pomi, R., Astrup, T., Hjelmar, O., Mostbauer, P., Cappai, G., Magel, G., Salhofer, S., Speiser, C., Heuss-Assbichler, S., Klein, R, Lechner, P. pHOENIX Working Group on Management of MSWI Residues, 2003. Management of municipal solid waste incineration residues. Waste Manag. (New York N.Y.) 23 (1), 61-88. http://dx.doi.org/10.1016/S0956-053X(02)00161-7.

Saffarzadeh, Amirhomayoun, Shimaoka, Takayuki, Wei, Yunmei, Gardner, Kevin H., Musselman, Craig N., 2011. Impacts of natural weathering on the transformation/neoformation processes in landfilled MSWI bottom ash: a geoenvironmental perspective. Waste Manag. 31 (12), 2440-2454. http:// dx.doi.org/10.1016/j.wasman.2011.07.017.

Sajedi, Fathollah, Razak, Hashim Abdul, 2011. Comparison of different methods for activation of ordinary Portland cement-slag mortars. Constr. Build. Mater. 25 (1), 30-38. http://dx.doi.org/10.1016/j.conbuildmat.2010.06.060.

Sathonsaowaphak, A., Chindaprasirt, P., Pimraksa, K., 2009. Workability and strength of lignite bottom ash geopolymer mortar. J. Hazard. Mater. 168 (1), 
44-50. http://dx.doi.org/10.1016/j.jhazmat.2009.01.120.

[WWW Document]. Soil Quality Decree, 2015. URL. http://wetten.overheid.nl/ BWBR0023085/BijlageA/geldigheidsdatum_09-10-2015.

Tang, P., Florea, M.V.A., Spiesz, P., Brouwers, H.J., 2014a. The investigation of the MSWI bottom ash fines ( $0-2 \mathrm{~mm})$ as binder substitute after combined treatments. In: EurAsia Waste Manag. Symp. April 2014, YTU 2010 Congr. Center, Istanbul/Turkiye, pp. 126-130.

Tang, P., Florea, M.V.A., Spiesz, P., Brouwers, H.J., 2014b. The application of treated bottom ash in mortar as cement replacement. In: EurAsia Waste Manag. Symp. April 2014, YTU 2010 Congr. Center, Istanbul/Turkiye, pp. 1077-1082.

Targan, Ş., Olgun, A., Erdogan, Y., Sevinc, V., 2003. Influence of natural pozzolan, colemanite ore waste, bottom ash, and fly ash on the properties of Portland cement. Cem. Concr. Res. 33, 1175-1182. http://dx.doi.org/10.1016/S00088846(03)00025-5.
Temuujin, J., Williams, R.P., van Riessen, A., 2009. Effect of mechanical activation of fly ash on the properties of geopolymer cured at ambient temperature. J. Mater. Process. Technol. 209 (12-13), 5276-5280. http://dx.doi.org/10.1016/ j.jmatprotec.2009.03.016.

van Deventer, J.S., Provis, J.L., Duxson, P., Lukey, G.C., 2007. Reaction mechanisms in the geopolymeric conversion of inorganic waste to useful products. J. Hazard. Mater. 139 (3), 506-513. http://dx.doi.org/10.1016/j.jhazmat.2006.02.044.

Zhen, Guangyin, Lu, Xueqin, Zhao, Youcai, Niu, Jing, Chai, Xiaoli, Su, Lianghu, Li, YuYou, Liu, Yuan, Du, Jingru, Hojo, Toshimasa, Hu, Yong, 2013. Characterization of controlled low-strength material obtained from dewatered sludge and refuse incineration bottom ash: mechanical and microstructural perspectives. J. Environ. Manag. 129, 183-189. http://dx.doi.org/10.1016 